\title{
PROCESY ZACHODZĄCE W GRUPIE NAJWIĘKSZYCH KORPORACJI AMERYKAŃSKICH W LATACH 1955-2011
}

\section{WSTĘP}

Procesy integracji i dezintegracji ekonomicznej można rozpatrywać na wielu płaszczyznach. Jedną z nich jest niewątpliwie płaszczyzna mikroekonomiczna. W samej mikroekonomii jednak terminy te rozumiane są wielorako. Jednym $\mathrm{z}$ takich zastosowań może być określanie stopnia konkurencji rynkowej na osi integracja-dezintegracja. Wysoki stopień integracji oznacza stabilizację, wskazującą na zanikanie konkurencji rynkowej. Siły dezintegracyjne, to z kolei wzmożone działanie konkurencji rynkowej, przejawiającej się w zmienności sytuacji poszczególnych jednostek gospodarczych. W ramach mikroekonomii, tak zdefiniowaną integrację i dezintegrację rozpatrywać można w grupie największych przedsiębiorstw na rynku.

Celem artykułu jest wielostronna analiza procesów ekonomicznych zachodzących w grupie 100 największych korporacji amerykańskich, w latach 1955-2011. Analiza ta odpowiedzieć ma na następujące pytania: czy grupa 100 największych korporacji amerykańskich jest mocno zwarta, tzn. trudno do niej wejść, czy też jest to grupa o dynamicznych i częstych zmianach uczestników? Czy pod tym względem jest to grupa mocno zintegrowana, czy też cały system gospodarczy wywiera na nią wpływ dezintegracyjny ${ }^{1}$ ?

${ }^{1}$ Poprzez zintegrowanie będzie rozumiane uodpornienie się przedsiębiorstw znajdujących się na liście na działanie konkurencji. Owe uodpornienie przejawiać się może przez stabilność lub wzrost siły 100 największych korporacji amerykańskich. Znaczna lub rosnąca zmienność na liście postrzegana będzie jako działanie konkurencji na rzecz dezintegracji listy i tym samym jeszcze silniejszej konkurencji. 
Artykuł podzielony jest na części, w których zawarte zostało odpowiednio: omówienie dotychczasowych badań nad zagadnieniem, przedstawienie własnych wyników oraz wnioski sformułowane na podstawie przeprowadzonych badań.

\section{DOTYCHCZASOWE BADANIA}

Bezpośrednim punktem odniesienia tego artykułu jest artykuł The Size Structure of the Largest Industrial Firms, 1909-1958 Normana R. Collinsa i Lee E. Prestona ${ }^{2}$. W artykule tym Autorzy analizie poddają 100 największych korporacji amerykańskich z sektora produkcji przemysłowej, wydobywczego oraz sektora dystrybucji, uszeregowanych według wielkości aktywów³. Poszczególnymi latami badania są: 1909, 1919, 1929, 1935, 1948 oraz 1958. W artykule przedstawionych jest kilka obszarów analizy listy korporacji, a prezentacja wybranych wyników tej analizy w tym miejscu wydaje się uzasadniona ze względu na możliwość późniejszego porównania wyników z pierwszej połowy $\mathrm{XX}$ wieku z jego drugą połową oraz pierwszą dekadą wieku XXI.

Rozkład 100 największych korporacji amerykańskich pod względem udziału w aktywach poszczególnych kwartyli, w badanym przez Collinsa i Prestona okresie uległ minimalnym zmianom. Wskazuje to na stabilną sytuację w tej kwestii wewnątrz grupy 100 korporacji. Krzywa Lorenza utrzymuje przez cały okres badania Collinsa-Prestona bardzo zbliżony kształt i pozycję. Do tożsamych wniosków prowadzą wartości współczynników koncentracji przedstawione w tabeli 1, które pokazują znaczenie kilku największych korporacji na liście 100 największych korporacji. Współczynnik koncentracji policzony został dla kolejno 4, 8 oraz 20 największych przedsiębiorstw. Od roku 1919, jak wskazują wartości przyjmowane przez niniejsze wskaźniki, sytuacja jest bardzo stabilna i nie można dopatrzyć się tutaj żadnych tendencji.

Tabela 2 przedstawia liczbę korporacji wypadających i wchodzących na listę największych korporacji. Pierwsze dwa okresy, tj. lata 1909-1919 oraz 1919-1929 to okresy dość znaczącej liczby wchodzących/wychodzących z listy ${ }^{4}$.

${ }^{2}$ N. R. Collins, L. E. Preston, The Size Structure of the Largest Industrial Firms, 1909-1958, „The American Economic Review”, t. 51, nr 5 (grudzień 1961), s. 986-1011.

${ }^{3}$ Wszystkie dalsze odwołania do artykułu Collinsa i Prestona dotyczyć będą 100 największych korporacji z wymienionych sektorów. Z badania Collinsa-Prestona wyłączone zostało rolnictwo, transport, sektor publiczny i sektor finansowy.

${ }^{4}$ Collins i Preston w pewnym stopniu tłumaczą to ówczesną dużą liczbą połączeń przedsiębiorstw oraz także dużą liczbą sądownie zasądzanych podziałów firm. 
Tabela 1. Współczynnik koncentracji, wyjścia i wejścia w 100 największych korporacjach amerykańskich w wybranych sektorach i latach w okresie 1909-1958

\begin{tabular}{|l|c|c|c|c|c|c|}
\hline WsPótCZYNNIK KONCENTRACJ゙* & 1909 & 1919 & 1929 & 1935 & 1948 & 1958 \\
\hline 4 największe & 32,2 & 23,9 & 21,0 & 23,5 & 21,4 & 22,7 \\
\hline 8 największych & 39,4 & 32,2 & 31,0 & 34,3 & 31,8 & 33,9 \\
\hline 20 największych & 55,2 & 49,8 & 51,3 & 53,7 & 52,5 & 54,1 \\
\hline
\end{tabular}

* Współczynnik policzony jako udział wartości aktywów kolejno 4, 8 oraz 20 największych korporacji pod tym względem w sumie aktywów wszystkich 100 korporacji.

Źródło: N. R. Collins, L. E. Preston, The Size Structure of the Largest Industrial Firms, 1909-1958, „The American Economic Review", vol. 51, no. 5 (grudzień 1961), s. 989.

Tabela 2. Liczba firm wypadających i wchodzących na listę 100 największych korporacji oraz procentowy udział wartości aktywów tych firm w aktywach korporacji ogółem z całej listy w podokresach w latach 1909-1958

\begin{tabular}{|l|c|c|c|c|c|}
\hline \multicolumn{1}{|c|}{ WYŚ́CIA } & $1909-1919$ & $1919-1929$ & $1929-1935$ & $1935-1948$ & $1948-1958$ \\
\hline Liczba* $^{*}$ & 40 & 31 & 16 & 20 & 16 \\
\hline Procent aktywów** & 17,8 & 19,0 & 7,5 & 7,8 & 6,0 \\
\hline Wejścia & 40 & 31 & 16 & 20 & 16 \\
\hline Liczba* $^{*}$ & 31,3 & 18,5 & 5,6 & 8,9 & 8,2 \\
\hline Procent aktywów** &
\end{tabular}

* Liczba wejść i wyjść z listy jest obliczona przez porównanie list z roku z początku podokresu z listą z roku końcowego podokresu. Oczywiście liczbie wyjść z listy odpowiada tożsama liczba wejść na listę; ${ }^{\star \star}$ Procent aktywów jest policzony jako suma aktywów firm wychodzących/wchodzących na listę do sumy aktywów wszystkich firm na liście na początku/na końcu okresu.

Źródło: N. R. Collins, L. E. Preston, op. cit., s. 989.

W późniejszych okresach sytuacja ta ulega stabilizacji i coraz mniej korporacji wypada $z$ listy $i$, tym samym, jest nowych na liście. Jednak jak zauważają Autorzy artykułu, aż 109 (44\%) z ogólnej liczby wejść i wyjść w całym badanym okresie $(246)^{5}$, to korporacje umiejscowione w ostatniej, piątej części listy. Zdecydowanie rzadziej ruchy dotyczyły korporacji z wyższych części listy ${ }^{6}$.

W tabeli 2 warto jeszcze zauważyć procentową wartość aktywów firm opuszczających listę oraz wchodzących na listę w tym samym okresie. W okresie 1919-1929 oraz 1929-1935 stosunek wartości aktywów firm wychodzących do wartości aktywów całej setki firm w porównaniu do stosunku wartości firm wchodzących na listę do wartości aktywów całej setki w tym roku,

5 Dla korporacji wypadających z listy dla pierwszego roku danego okresu, a dla pojawiających się na liście dla roku ostatniego.

${ }^{6}$ N. R. Collins, L. E. Preston, op. cit., s. 990. 
był wyższy. W pozostałych trzech okresach to relatywna wartość firm wchodzących na listę była większa niż relatywna wartość firm wychodzących. W tej statystyce zawarta jest informacja o powodach ruchów na liście - czy były one spowodowane spadkiem wartości firm znajdujących się na niej, czy też rosnącą wartością firm wchodzących. W cytowanych badaniach w pierwszym, czwartym i piątym podokresie wskazać należy na rosnącą wartość firm wchodzących, z kolei w okresie drugim i trzecim raczej na słabość firm wypadających $\mathrm{z}$ listy.

Collins i Preston analizie poddali także zależność pomiędzy pozycjami na liście zajmowanymi przez firmy, które były na niej zarówno na początku jak i na końcu podokresu (np. w 1909 roku oraz 1919; dla tego podokresu było to 60 przedsiębiorstw). Zależność tę zbadali współczynnikiem korelacji Spearmana. Jak widać w pierwszym wierszu tabeli 3 współczynnik korelacji z okresu na okres wzrasta. Uwzględnić należy, że trzeci okres jest krótszy niż pozostałe, co zwykle ma duże znaczenie dla wartości współczynnika. Niemniej Autorzy stwierdzają większą jego stabilność w ostatnich dwóch okresach w porównaniu do dwóch pierwszych, co oznacza większą zależność pomiędzy pozycją firmy na liście na początku danego podokresu i na jego końcu ${ }^{7}$.

Tabela 3. Współczynnik korelacji pomiędzy pozycjami firm na liście oraz współczynniki wzrostu wartości aktywów

\begin{tabular}{|l|c|c|c|c|c|}
\hline \multicolumn{1}{|c|}{ WyszczególnienIE } & $1909-1919$ & $1919-1929$ & $1929-1935$ & $1935-1948$ & $1948-1958$ \\
\hline $\begin{array}{l}\text { Współczynnik korelacji pomiędzy pozycjami } \\
\text { W rankingu firm występujących na liście na po- } \\
\text { zzątku oraz na końcu podokresu }\end{array}$ & 0,65 & 0,70 & 0,89 & 0,83 & 0,79 \\
\hline Współczynnik wzrostu: & \multicolumn{5}{|l|}{} \\
\hline $\begin{array}{l}\text { wartości aktywów 100 przedsiębiorstw (średnio- } \\
\text { roczna zmiana) }\end{array}$ & 7,74 & 5,28 & $-2,55$ & 5,28 & 8,32 \\
\hline $\begin{array}{l}\text { wartości aktywów przedsiębiorstw, które były } \\
\text { na liście na początku oraz na końcu podokresu } \\
\text { (średnioroczna zmiana) }\end{array}$ & 5,83 & 5,80 & $-2,22$ & 5,19 & 8,09 \\
\hline
\end{tabular}

Źródło: N. R. Collins, L. E. Preston, op. cit., s. 992.

Ciekawych wniosków dostarczają powyższe dane w zestawieniu ze stopami wzrostu przedstawionymi także w tabeli 3. Zauważyć należy, że jeżeli wartość średniorocznej stopy wzrostu wartości aktywów całej setki przedsiębiorstw przewyższa wartość średniorocznej stopy wzrostu firm pozostałych na liście, tak jak np. w pierwszym podokresie, to średnioroczne tempo wzrostu nowych firm na liście jest większe, niż tych pozostałych na liście. Dość czytelnie ko-

7 Ibidem, s. 991. 
responduje to z wartościami współczynnika korelacji, omówionymi wcześniej - jeśli ta różnica jest duża, na stosunkowo niższym poziomie kształtuje się współczynnik korelacji; jeśli ta różnica jest niewielka, współczynnik korelacji przybiera wyższe wartości.

Collins i Preston konkludują: w okresie objętym badaniem, tj. w latach 1909-1958 nastąpił spadek liczby korporacji wypadających/wchodzących na listę; spadek ruchów wewnątrz listy przejawiający się rosnącym współczynnikiem korelacji pozycji zajmowanych na początku oraz na końcu podokresu; pojawiła się niewielka tendencja w kierunku mniejszego zróżnicowania korporacji na liście pod względem wartości aktywów ${ }^{8}$. Można zatem podsumować, że wyniki przedstawione przez Collinsa-Prestona pozwalają stwierdzić znaczne i rosnące zintegrowanie listy 100 największych korporacji amerykańskich oraz słabnące oddziaływanie dezintegracyjnych sił rynkowych.

Collins i Preston polemizują $\mathrm{w}$ swoim artykule $\mathrm{z}$ badaniami przeprowadzonymi przez Abrahama D. H. Kaplana, a opublikowanymi w Big Enterprise in a Competitive System ${ }^{9}$. Kaplan stwierdza, że pierwsza połowa XX wieku to okres znaczącej konkurencji i niestabilności pozycji przedsiębiorstw znajdujących się na liście 100 największych amerykańskich korporacji przemysłowych. Utrzymanie się na liście wymaga zatem wysiłku i jest zdecydowanie niepew$n e^{10}$. Collins i Preston stwierdzają, że sytuacja na liście jest stabilna i przewidywalna, że im przedsiębiorstwo większe, tym łatwiej mu utrzymać swoją pozycję w przyszłości.

Badania Collinsa i Prestona uaktualnił Robert J. Stonebraker ${ }^{11}$, przedłużając je o dwa podokresy, tj. 1958-1967 i 1967-1976. Na podstawie wyników swoich badań stwierdzał, że: nie można potwierdzić spadającej liczby wyjść i wejść na listę ${ }^{12}$; współczynnik korelacji pomiędzy pozycjami zajmowanymi na liście utrzymuje bardzo zbliżone wartości do wcześniejszych ${ }^{13}$; także sta-

${ }^{8}$ Ibidem, s. 1001. Wnioski o rosnącej zdolności do utrzymywania się na liście i konsolidowania listy 100 największych korporacji amerykańskich w miarę bycia coraz większym przedsiębiorstwem wyciąga także David Mermelstein. Mermelstein w swoim badaniu opiera się jednak na wartościach akcji. Zob. D. Mermelstein, Large Industrial Corporations and Asset Shares, „The American Economic Review”, t. 59, nr 4, cz. 1 (wrzesień 1969), s. 531-541.

9 A. D. H. Kaplan, Big Enterprise In a Competitive System, Brookings Institution, Washington 1954.

${ }^{10}$ Ibidem, s. 18. Mermelstein zarzuca Kaplanowi, że posługiwał się prymitywną metodą „przychodową”; D. Mermelstein, op. cit., s. 531.

${ }_{11}$ R. J. Stonebraker, Turnover and Mobility among the 100 Largest Firms: An Update, „The American Economic Review”, t. 69, nr 5 (grudzień 1979), s. 968-973.

12 Dla podokresu 1958-1967 było to 21, a dla 1967-1976 - 18. R. J. Stonebraker, op. cit., s. 969,972 .

${ }^{13}$ Dla lat 1958-1976 to 0,81, a dla lat 1967-1976 - 0,80. Ibidem, s. 970. 
bilne jest zróżnicowanie między poszczególnymi korporacjami pod względem wartości aktywów ${ }^{14}$. Podsumowując, Autor stwierdza, że korporacje w badanym okresie nie zwiększyły swojej odporności na konkurencję.

\section{BADANIE PROCESÓW ZACHODZĄCYCH WŚRÓD NAJWIĘKSZYCH KORPORACJI AMERYKAŃSKICH}

Badanie, które zostanie opisane w niniejszym artykule, przeprowadzono na podstawie listy Fortune 500 dla największych korporacji amerykańskich. Z listy tej do badania użyto 100 pierwszych korporacji w latach 1955-2011 ${ }^{15}$, gdzie kryterium wielkości stanowiła wartość aktywów ${ }^{16}$. Okres podzielono na pięcioletnie podokresy ${ }^{17}$. Z listy nie wyłączono przedsiębiorstw $z$ sektora finansowego, tak jak w przytaczanych powyżej badaniach, ponieważ ich uwzględnienie prowadzi do ciekawych obserwacji i wniosków końcowych. Miernikami statystycznymi będącymi podstawą formułowania późniejszych wniosków są: współczynnik koncentracji ${ }^{18}$, współczynnik Lorenza, relatywne tempo wzrostu wartości aktywów, statystyka „wejść” i „wyjść” z listy oraz inne statystyki unaoczniające skalę zachodzących zmian.

Wykres 1 przedstawia krzywe Lorenza dla wybranych lat w okresie 1955-2010. Obrazują one rozkład wartości aktywów na liście 100 największych korporacji amerykańskich. Im krzywa Lorenza bliższa jest osi 45 stopni, tym bardziej zbliżone do siebie pod względem wartości aktywów są poszczególne przedsiębiorstwa na liście. Rok początkowy w badaniu, tj. rok 1955, zaznaczo-

${ }^{14}$ Ibidem, s. 969.

15 Baza Fortune 500 jest zorganizowana w dwojaki sposób. Od 1955 do 2005 roku jest ona uporządkowana według aktywów. Od 2006 roku uszeregowana jest jednak według wielkości przychodów korporacji w danym roku, co oczywiście nie pokrywa się z listą, w której kryterium jest wartość aktywów. W takim wypadku tworzono listę największych 100 korporacji amerykańskich pod względem wielkości aktywów na podstawie wszystkich 500 firm publikowanych w rankingu Fortune 500.

16 Aktywa jako kryterium uporządkowania 100 największych korporacji przyjęto, by umożliwić porównywalność pomiędzy przywołanymi wcześniej badaniami oraz ze względu na najmniejszą podatność wartości aktywów na wahania przypadkowe. Dyskusja o wszelkich miarach wielkości korporacji zob. M. A. Adelman, The Measurement of Industrial Concentration, „The Review of Economics and Statistics”, t. 33, nr 4 (listopad 1951), s. 269-296.

17 Przy niektórych wskaźnikach, kiedy wykazywały one ponadnormalną zmienność, wzięto pod uwagę więcej lat niż tylko rok początkowy i końcowy danego podokresu, by zlokalizować początek zmian.

${ }^{18}$ Dla 4, 8 oraz 20 największych przedsiębiorstw. 
ny jest linią ciągłą. Krzywa Lorenza dla kolejnych lat przesuwała się zarówno w kierunku osi 45 stopni, jak i w kierunku przeciwnym.

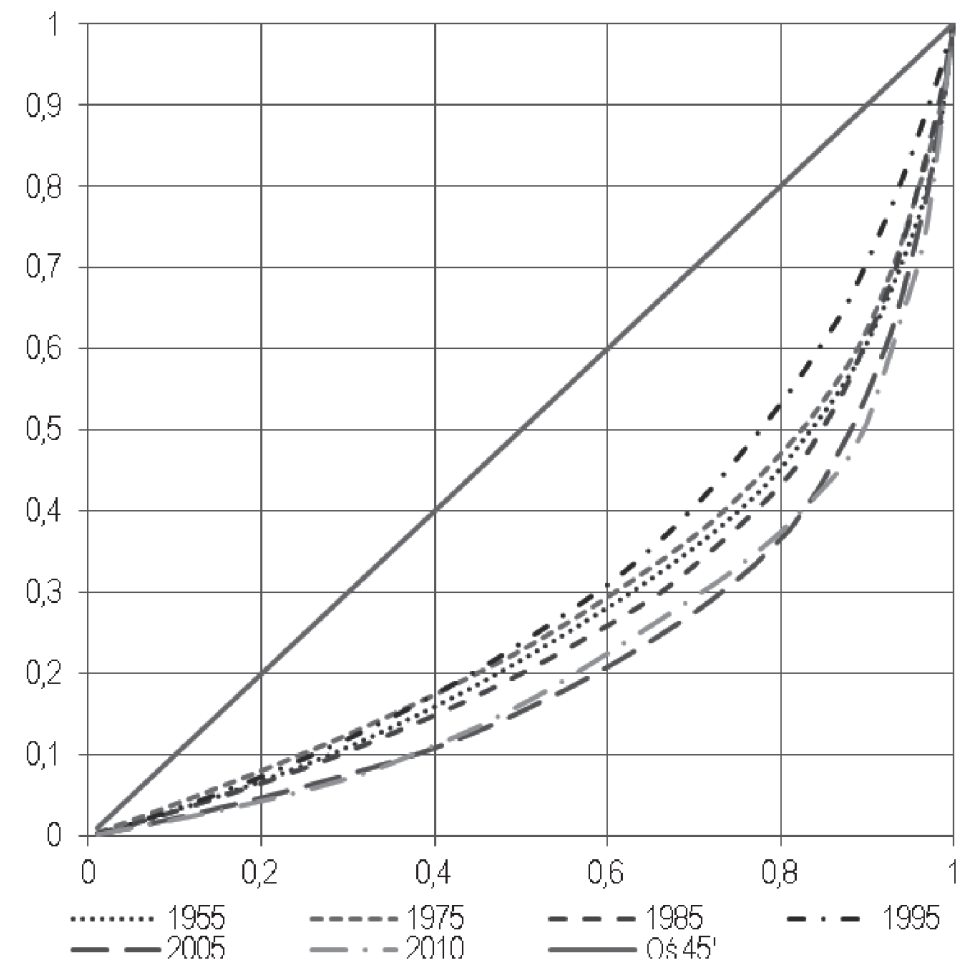

Wykres 1. Krzywe Lorenza dla rozkładu wartości aktywów 100 największych korporacji amerykańskich w latach 1955, 1975, 1985, 1995, 2005, 2010

Źródło: opracowanie własne na podstawie Fortune 500.

Nie można zatem sformułować w stosunku do całego badanego okresu 1955-2011 ogólnego wniosku o trendzie w tej kwestii. Najbardziej oddalone od osi 45 stopni są krzywe Lorenza wykreślone dla lat 2005 i 2010. Właśnie w 2010 roku pierwsza piąta część korporacji, uszeregowanych od najmniejszych wartości aktywów do największych, obejmowała 4,3\% wartości aktywów całej setki firm; $40 \%$ firm obejmowało $11 \%$ wartości aktywów, $60 \%$ obejmowało $22,5 \%$, a $80 \%$ przedsiębiorstw obejmowało $37,4 \%$. Najbardziej zbliżona do osi 45 stopni była krzywa Lorenza dla 1995 roku. Rok 1995, jak będą to potwierdzały kolejne wyliczenia, jest dość istotnym i zwrotnym rokiem w całym badaniu. Potwierdzają to także wskaźniki, których wartości zobrazowane są na wykresie 2 . 
Wykres 2 przedstawia współczynniki koncentracji dla 4, 8 oraz 20 największych firm, a także współczynnik zmienności wartości aktywów oraz współczynnik Giniego. Wykres wartości współczynnika Giniego dostarcza bardziej szczegółowych obserwacji dynamiki nierównomierności rozkładu wartości aktywów między poszczególne firmy na liście 100 największych korporacji.

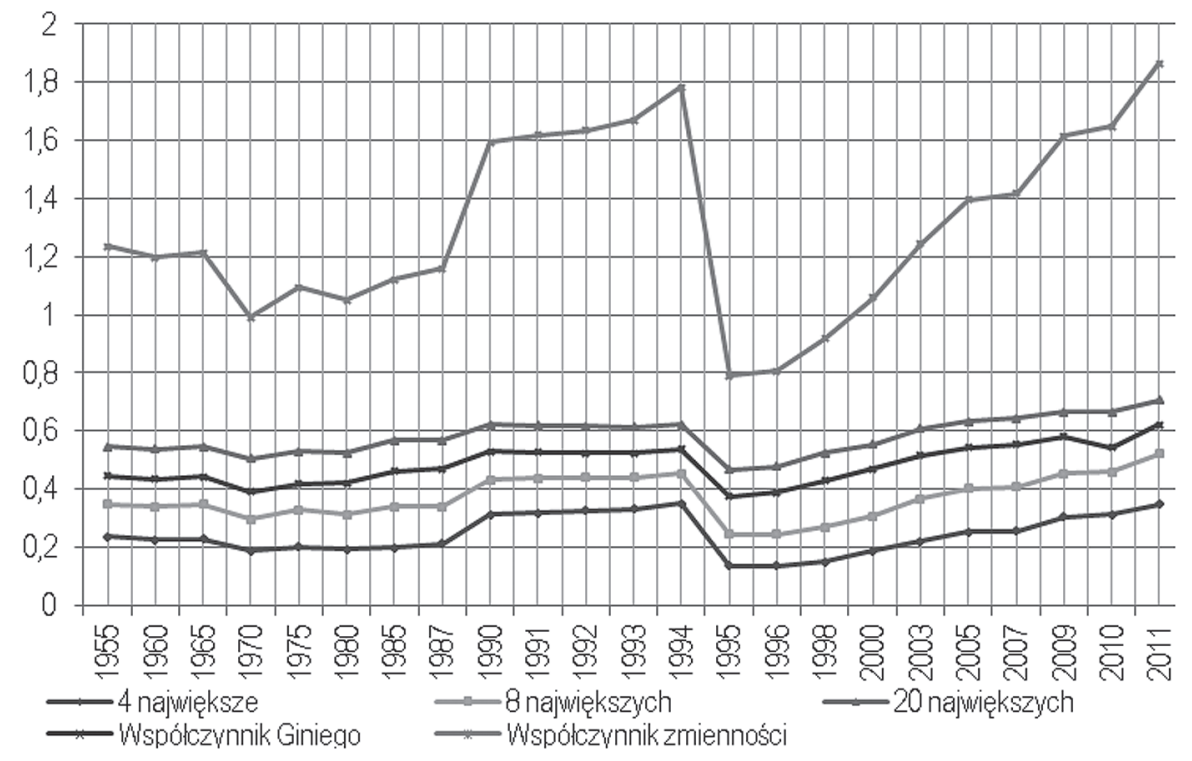

Wykres 2. Współczynnik koncentracji dla 4, 8 oraz 20 największych przedsiębiorstw z listy 100 oraz współczynnik Giniego i współczynnik zmienności wartości aktywów dla firm na liście w latach 1955-2011*

* Wartości niniejszych wskaźników policzone były dla lat: 1955, 1960, 1965, 1970, 1975, 1980, 1985, 1987, 1990, 1991, 1992, 1993, 1994, 1995, 1996, 1998, 2000, 2003, 2005, 2007, 2009, 2010, 2011. Większa częstość niektórych obserwacji podyktowana była koniecznością wyznaczenia początku niektórych gwałtownych zjawisk.

Źródło: opracowanie własne na podstawie Fortune 500.

Zgodnie z tym, co wskazywały wykresy krzywych Lorenza przedstawione na wykresie 1, nierównomierność rozkładu wartości aktywów pomiędzy przedsiębiorstwa na liście 100 największych korporacji amerykańskich od 1955 roku zmieniała się w różną stronę, raz rosnąć, raz spadając. Dynamice tego procesu oddać jednak należy względną stabilność, szczególnie w stosunku do procesów, które miały miejsce od połowy lat osiemdziesiątych. Wówczas współczynnik Giniego osiągnął nienotowane wcześniej wartości (w 1985 roku była to wartość 0,46) i rósł dalej w dość dużym tempie aż do roku 1994. Wówczas osiągnął szczytową wartość 0,54, by w 1995 ro- 
ku drastycznie spaść do 0,376. Od tamtego czasu wartość tego wskaźnika systematycznie rośnie, aż do kolejnych rekordów w latach 2010 i 2011 (odpowiednio 0,54 i 0,62 ).

Tożsame tendencje wykazują inne wskaźniki przedstawione na wykresie 2. Współczynnik zmienności wartości aktywów 100 największych korporacji także mówi o zróżnicowaniu wartości aktywów firm na liście. Oprócz tego, że potwierdza przedstawione za pomocą współczynnika Giniego i krzywych Lorenza duże zróżnicowanie poszczególnych firm pod względem wartości aktywów, to bardziej unaocznia to, co miało miejsce w połowie lat 90 . Zdecydowany spadek wartości współczynnika zmienności oraz omówionych wyżej dwóch innych miar zróżnicowania wewnętrznego listy korporacji, oznacza skokowe zmniejszenie się nierówności pod względem aktywów pomiędzy firmami znajdującymi się na liście właśnie w połowie lat 90 . Niemniej, na wykresie 2 zaobserwować można także szybki wzrost współczynnika zmienności, tak, że w 2011 roku osiągnął on wartość nie notowaną wcześniej.

Tożsamą tendencję pokazują współczynniki koncentracji 4, 8 oraz 20 największych przedsiębiorstw na liście - pozioma tendencja do połowy lat 80., stosunkowo szybki wzrost do roku 1994 oraz gwałtowny spadek w 1995 roku. Oznaczało to spadek znaczenia wartości aktywów liderów listy 100 największych korporacji amerykańskich. Jednak począwszy właśnie od 1995 roku ich znaczenie zaczyna na powrót szybko rosnać, by z końcem badanego okresu osiągnąć wynik zbliżony (dla 4 największych) lub wyższy niż ten w 1994 roku (dla 8 i 20 największych korporacji).

Takie obserwacje mogą prowadzić do dwóch odmiennych wniosków odnośnie ich przyczyn. Takie zjawiska mogły być wywołane przez zdecydowany spadek wartości aktywów przedsiębiorstw będących w górnej części listy, albo zdecydowany wzrost wartości aktywów przedsiębiorstw w dolnej jej części, na skutek czego doszło do względnego wyrównania wartości aktywów wszystkich firm znajdujących się na liście. Do odpowiedzi na to pytanie przydatne będą wskaźniki przedstawione na wykresie 3. Prezentuje on stosunek sumy aktywów przedsiębiorstw znajdujących się na liście 100 największych korporacji do amerykańskiego PKB w danym roku oraz do wartości aktywów wszystkich amerykańskich korporacji.

Stosunek wartości sumy aktywów korporacji na liście do wartości sumy aktywów wszystkich korporacji amerykańskich pokazuje skokowy wzrost wartości tych pierwszych. Tak jak wyżej, zmiana ta dokonała się z 1994 na 1995 rok. W porównaniu jednak do zmian drugiego wskaźnika przedstawionego na wykresie 3 jest to zmiana stosunkowo niewielka. Także na stabilnym i względnie niskim poziomie kształtował się stosunek wartości sumy aktywów stu największych korporacji do amerykańskiego PKB. W 1994 roku nastąpił jednak 
znaczący wzrost wartości aktywów 100 największych korporacji, tak że ich stosunek do PKB gospodarki amerykańskiej wzrósł z 0,3 do 0,95 w roku 1995 i dalej wzrastał w szybkim tempie. W 2011 roku osiągnął on wartość 1,88 razy większą niż wartość PKB w tym roku.

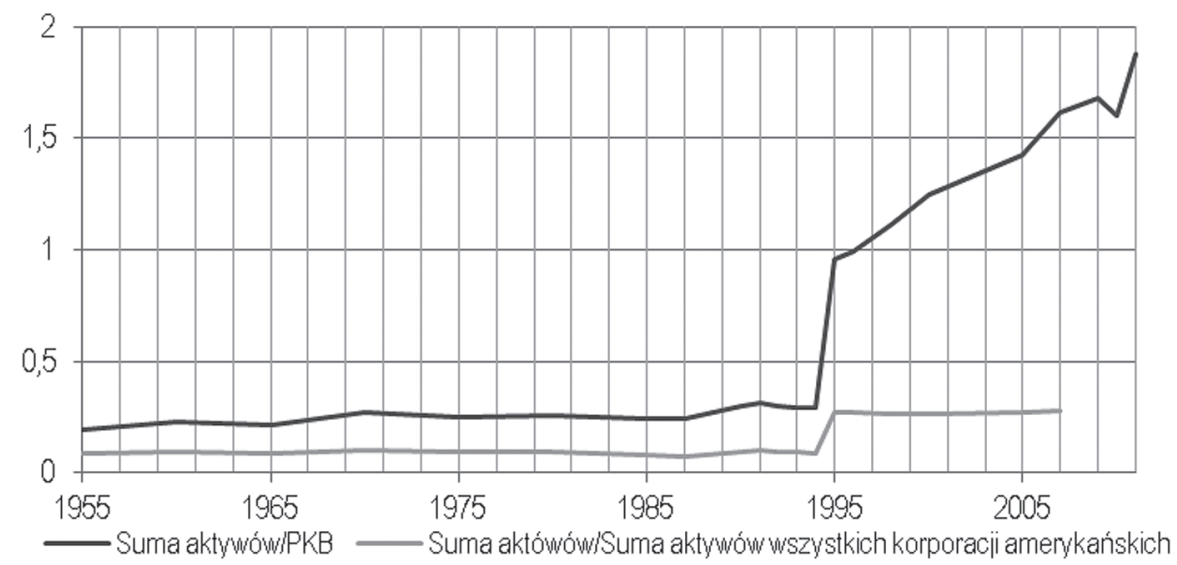

Wykres 3. Stosunek wartości aktywów 100 największych korporacji amerykańskich do wartości PKB gospodarki amerykańskiej w latach 1955-2011 oraz do wartości aktywów wszystkich amerykańskich korporacji w latach 1955-2007

Źródło: opracowanie własne na podstawie: Fortune 500, Statistical Abstract of United States; PKB USA w 2011 roku według prognozy OECD.

Wykres 4 przedstawia stosunek wartości aktywów przedsiębiorstw, które zajmowały w poszczególnych latach pozycję 1, 5, 25 oraz 50 na liście do wartości PKB Stanów Zjednoczonych. Na podstawie wskaźników przedstawionych na tym wykresie oraz na wykresie 3 można odpowiedzieć na pytanie co było powodem skokowego zmniejszenia się zróżnicowania wartości aktywów między przedsiębiorstwami na liście 100 największych korporacji amerykańskich. Zjawisko to nie wynika, co było jedną z dwóch ewentualności, ze spadku wartości aktywów przedsiębiorstw znajdujących się w górnej części listy, ponieważ skutkowałoby to spadkiem sumy wartości aktywów przedsiębiorstw na liście oraz spadkiem wartości aktywów liderów listy, a przeczą temu wartości zaprezentowane na wykresie 3 oraz 4. Suma wartości aktywów wszystkich firm na liście w stosunku do amerykańskiego PKB gwałtownie wzrosła w 1995 roku. W mniejszym stopniu wzrosła w stosunku do wartości aktywów wszystkich amerykańskich korporacji, co wskazuje na to, że także sytuacja całej tej grupy przedsiębiorstw znacząco się poprawia. 


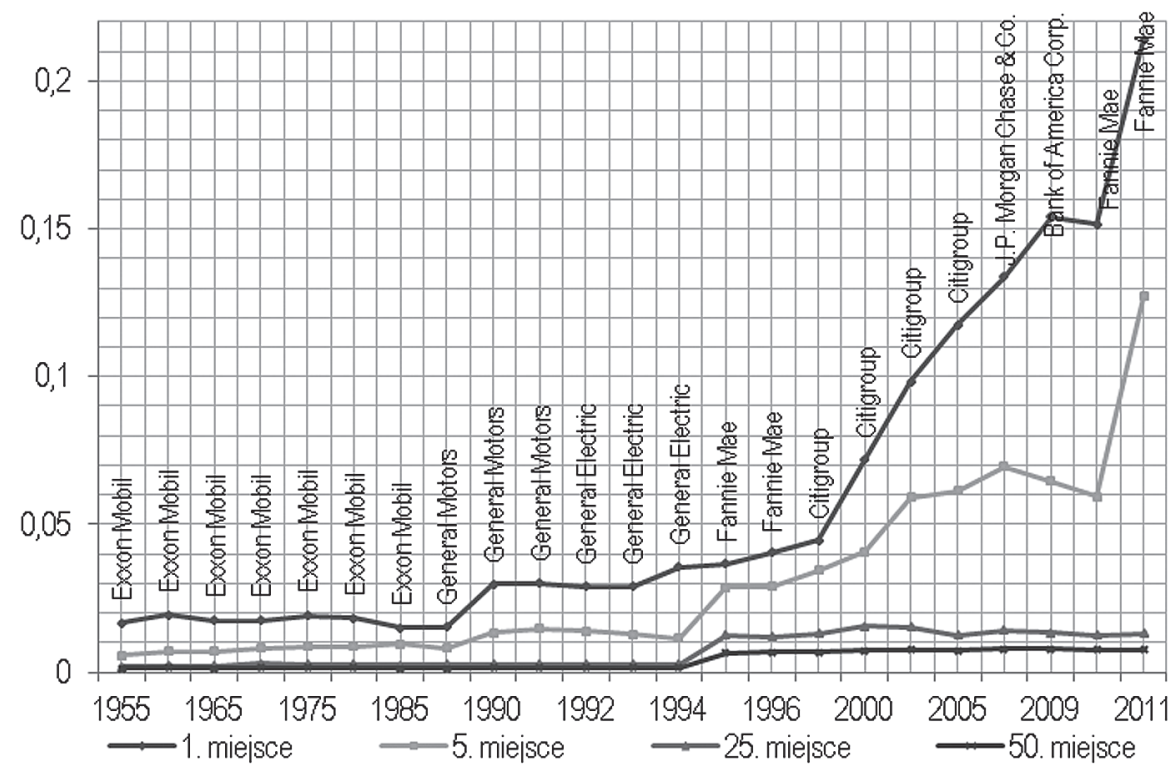

Wykres 4. Stosunek wartości aktywów kolejno 1. korporacji na liście, 5., 25., oraz 50. do wartości PKB Stanów Zjednoczonych

Źródło: opracowanie własne na podstawie Fortune 500 oraz Statistical Abstract of United States.

Wykres 4 potwierdza, że nie nastąpił spadek wartości aktywów korporacji z żadnego $\mathrm{z}$ przytoczonych miejsc $\mathrm{w}$ relacji do $\mathrm{PKB}$. Wręcz przeciwnie - wartość tej relacji rośnie mniej lub bardziej, ale zarówno dla 1, 5, 25 oraz 50 miejsca od 1994 roku. $Z$ wykresu 4 wyciągnąć można jeszcze kilka ciekawych wniosków. Po pierwsze, bardzo widoczna jest względna stabilność przytoczonych wskaźników do 1987 roku. Jest to szczególnie widoczne dla 1 pozycji na liście. W korespondencji do wcześniej przedstawionych statystyk, oraz opisanych wcześniej badań Collinsa-Prestona i Stonebrakera, sytuację na liście do roku 1987 można ocenić jako stabilną. Dodatkowo, wart odnotowania jest też fakt, że dla okresu 1955-1994 pierwsze miejsce zajmowało przedsiębiorstwo z sektora przemysłowego ${ }^{19}$. Coraz większa wartość aktywów pierwszego przedsiębiorstwa w stosunku do PKB od 1987 do 1994 roku jest wyrazem rosnącej w szybszym tempie niż gospodarka USA wartości aktywów tych

${ }^{19} \mathrm{~W}$ okresie 39 lat, tj. od 1955 do 1994 roku pierwsze miejsce na liście 100 największych korporacji pod względem aktywów zajmowały tylko trzy korporacje - w latach 1955-1986 pierwsze miejsce nieprzerwanie zajmowało Exxon Mobil, w latach 1987-1992 General Motors, a w latach 1993 i 1994 General Electic. 
firm ${ }^{20}$. Symboliczna ale i bardzo wymowna była zmiana na pierwszym miejscu na liście w 1995 roku. W tym roku pierwszy raz na szczycie listy jest korporacja nie $z$ sektora przemysłowego, a $z$ sektora finansowego. Ta sytuacja utrzymała się do końca okresu objętego badaniem. Uderzający jest też niezwykle szybki od momentu tej zmiany wzrost wartości stosunku aktywów pierwszej firmy na liście do PKB Stanów Zjednoczonych. W 2011 roku osiaga on niewiarygodną wartość 21\% PKB największej gospodarki na świecie.

Tabela 4 przedstawia jedną $\mathrm{z}$ ważniejszych statystyk opisujących procesy zachodzące $\mathrm{w}$ grupie stu największych korporacji amerykańskich - statystyki wejść i wyjść z listy. Tabela przedstawia współczynnik korelacji pomiędzy pozycją w rankingu zajmowaną przez daną firmę na początku podokresu, a pozycją zajmowaną przez tę samą firmę w ostatnim roku danego podokresu ${ }^{21}$, stosunek wartości aktywów firm pojawiających się na liście do wartości aktywów firm znikających z listy oraz liczbę wejść i wyjść z listy.

Tabela 4. Statystyki wejść i wyjść z listy 100 największych korporacji amerykańskich w latach 1955-2010

\begin{tabular}{|c|c|c|c|}
\hline LATA & KORELACIA MIĘDZY POZYCJAMI W RANKINGU & WCHODZACE/WYCHODZACE & LICZBA \\
\hline $1955-1960$ & 0,881 & 3,32 & 11 \\
\hline $1960-1965$ & 0,903 & 1,38 & 11 \\
\hline $1965-1970$ & 0,834 & 2,31 & 24 \\
\hline $1970-1975$ & 0,850 & 1,07 & 12 \\
\hline $1975-1980$ & 0,881 & 1,69 & 13 \\
\hline $1980-1985$ & 0,840 & 0,90 & 22 \\
\hline $1985-1990$ & 0,838 & 1,05 & 24 \\
\hline $1990-1995$ & 0,872 & 8,08 & 41 \\
\hline $1995-2000$ & 0,722 & 1,13 & 30 \\
\hline $2000-2005$ & 0,830 & 0,57 & 28 \\
\hline $2005-2010$ & 0,855 & 1,02 & \\
\hline
\end{tabular}

Źródło: opracowanie własne na podstawie Fortune 500.

Współczynnik korelacji pomiędzy pozycjami zajmowanymi przez daną firmę na początku i na końcu danego okresu, poza podokresem 1995-2000 $(0,722)$ uznać należy za wysoki i stabilny. Oznacza to, że pozycja zajmowana przez firmę na początku danego podokresu ma znaczący wpływ na to, ja-

${ }^{20}$ Taka obserwacja, podparta dogłębnymi badaniami, mogłaby posłużyć jako podstawa do zweryfikowania hipotezy o rosnącym tempie globalizacji od tamtego okresu. Wskazuje na to właśnie wzrost aktywów danych przedsiębiorstw szybszy niż wzrost gospodarki Stanów Zjednoczonych.

${ }^{21} \mathrm{~Np}$. dla pierwszego podokresu współczynnik korelacji policzony został dla 89 firm, ponieważ tyle firm przetrwało cały ten podokres. 
ką pozycję zajmie ta firma na koniec tego podokresu. Nawet w okresie „szoku”, kiedy to aż 82 firmy zniknęły z listy, współczynnik korelacji jest wysoki $(0,872)$, co świadczy o tym, że dla firm które pozostały na liście, zależność zajmowanego przez nie miejsca ma duży wpływ na ich miejsce w późniejszym czasie tego podokresu.

Kolumna „wchodzące/wychodzące” to stosunek wartości aktywów przedsiębiorstw, które weszły na listę 100 największych korporacji amerykańskich w danym podokresie do wartości aktywów przedsiębiorstw, które z tej listy zniknęły. Jeżeli wartość tego wskaźnika jest większa od 1 znaczy to, że wartość aktywów firm wchodzących na listę przewyższała wartość aktywów firm $\mathrm{z}$ listy wypadających. Przede wszystkim należy zauważyć, że tylko w dwóch $\mathrm{z}$ jedenastu podokresów wskaźnik ten ma wartość niższą od jedności. W pozostałych przypadkach wchodzące firmy więcej „wnosiły” niż znikające „zabierały" aktywów ze sobą. Uderzająca jest wartość wskaźnika dla podokresu 1990-1995, kiedy wynosi on 8,08. Oznacza to, że wartość aktywów nowych przedsiębiorstw ponad ośmiokrotnie przekraczała wartość aktywów przedsiębiorstw, które z listy wypadły.

Ciekawie w odniesieniu do formułowanych już wcześniej wniosków kształtują się dane zawarte w kolumnie „liczba”. Podana jest tam liczba korporacji która $\mathrm{w}$ danym podokresie zniknęła $\mathrm{z}$ listy, ale i zarazem liczba nowych korporacji w tymże podokresie. Okres od 1955 roku do roku 1990 uznać można za stabilny; liczba wyjść/wejść na listę zawiera się w przedziale od 11 do 24 . W kolejnym okresie, tj. 1990-1995, przez listę 100 największych korporacji amerykańskich przeszedł huragan. $Z$ listy zniknęły/pojawiły się na niej aż 82 przedsiębiorstwa. Tak jak wskazywały prezentowane wcześniej wykresy i statystyki, nie był to jednak żaden krach dotychczasowych liderów, a ogromna fala nowych i zdecydowanie większych korporacji, które wyparły z listy te stare. W kolejnych okresach sytuacja zdaje się powoli stabilizować, tzn. ilość wyjść/wejść na listę spada najpierw do 41, potem do 30, by osiągnąć w ostatnim podokresie liczbę 28 .

Pomocna w interpretowaniu statystyk dotyczących wyjść i wejść na listę będzie tabela 5 .

Tabela 5. Liczba wyjść i wejść z podziałem listy 100 największych korporacji amerykańskich na pięć części

\begin{tabular}{|l|c|l|l|l|l|l|}
\hline \multirow{2}{*}{ MIEJSCE NA LIŚCIE } & 1 DO 20 & 21 DO 40 & 41 DO 60 & 61 DO 80 & 81 DO 100 & \multicolumn{1}{c|}{ SUMA } \\
\hline \multirow{2}{*}{ Wyjś́cia } & 26 & 36 & 50 & 71 & 115 & 298 \\
\cline { 2 - 7 } & $8,72 \%$ & $12,08 \%$ & $16,78 \%$ & $23,83 \%$ & $38,59 \%$ & $100,00 \%$ \\
\hline \multirow{2}{*}{ Wejścia } & 26 & 37 & 45 & 72 & 118 & 298 \\
\cline { 2 - 7 } & $8,72 \%$ & $12,42 \%$ & $15,10 \%$ & $24,16 \%$ & $39,60 \%$ & $100,00 \%$ \\
\hline
\end{tabular}

Źródło: opracowanie własne na podstawie Fortune 500. 
Tabela przedstawia liczbę wyjść i wejść na listę 100 największych korporacji amerykańskich ze względu na odcinek listy, w którym dane ruchy się dokonały. Aż blisko 40\% spośród wszystkich 298 wyjść/wejść miało miejsce w ostatniej, piątej części listy, tj. na miejscach 81-100. Blisko 9\% liczby ogółu wyjść/wejść przypadająca na pierwszą piątą część listy wydaje się jednak dosyć istotna. Dodać jednak należy, że aż 19 spośród 26 wyjść z listy, które miały miejsce w odcinku między miejscami 1-20 na liście, zdarzyło się w ostatnich czterech podokresach (od 1990 do 2010 roku), czyli w okresie największej „zawieruchy" na liście. Podobnie zresztą było z liczbą wejść - aż 22 spośród 26 jakie dokonały się w najwyższej części listy, miało miejsce w ostatnich trzech podokresach (tj. od 1995 do 2010 roku). Wcześniej wszelkie wyjścia/wejścia na szczycie tabeli były zatem sporadyczne.

\section{ZAKOŃCZENIE}

Przeprowadzone badania pozwalają sformułować, nie sprzeczne, ale dość rozbieżne wnioski. Po pierwsze, na podstawie wszelkich analiz ilościowych, stwierdzić można bardzo istotne działanie sił rynkowych prowadzących do dezintegracji stabilnego układu rynkowego. Działanie tych sił określić można jako nieoczekiwane i bardzo silne. Przemawia za tym zmieniający się w pewnym momencie gwałtownie rozkład wartości aktywów przedsiębiorstw na liście, także gwałtowne i nieoczekiwane zmiany dotyczące statystyk wyjść i wejść na listę, czy też ogromne skoki wartości wskaźników aktywów do amerykańskiego PKB dla poszczególnych przedsiębiorstw. Trwająca przez cały okres badania, czyli od 1955 roku do roku 2011, a nawet sięgając do cytowanych wcześniej badań od początku XX wieku, stabilność funkcjonowania największych przedsiębiorstw na liście oraz ich znaczna siła, zostały „zmiecione” przez procesy, które zaszły w przełomowym w tym badaniu roku 1995. Oznacza to dużą niepewność sytuacji, co utożsamiać należy z przejawem działania dezintegracyjnych sił rynkowych, działających w kontrze do wszelkich działań integracyjnych mających ustabilizować i uczynić bardziej pewną sytuację przedsiębiorstw na rynku.

$Z$ drugiej jednak strony należy być świadomym specyfiki zmian jakie zaszły w gronie 100 największych korporacji amerykańskich. Zmiany te dotyczyły wyłącznie przedsiębiorstw $\mathrm{z}$ sektora finansowego. Zdecydowana większość przedsiębiorstw, które pojawiły się na liście w przełomowym 1995 roku, to przedsiębiorstwa finansowe. Włączenie sektora finansowego do badania nie przeszkadzało jego prowadzeniu i formułowaniu wniosków do momentu, kiedy uczestnicy tego sektora nie zdominowali listy 100 największych korpora- 
cji amerykańskich. Inną kwestią jest rzecz przyczyn takich zmian ${ }^{22}$. Niemniej, nim sektor finansowy zdominował procesy zachodzące na liście 100 największych korporacji amerykańskich, czyli do roku 1995, wydaje się uzasadnione sformułowanie następujących wniosków: sytuacja na liście wydaje się być bardzo stabilna do roku 1985 i w miarę stabilna z tendencją do wzrostu zróżnicowania w latach 1985-1995 pod względem zróżnicowania wartości aktywów przedsiębiorstw na liście. Ilustrują to rosnące wartości wskaźników koncentracji oraz wskaźnika zmienności począwszy od roku 1987. W tożsamym podziale na podokresy (od 1955 do 1985 i od 1985 do 1995 roku) przedstawia się sytuacja przedsiębiorstw zajmujących poszczególne pozycje na liście w relacji do amerykańskiego PKB. Również statystyki wejść i wyjść oraz korelacji między zajmowanymi pozycjami na liście wskazują na dużą stabilność sytuacji, jednak tu bez jakichkolwiek podstaw do wskazania tendencji.

Podsumowując, sformułowane wnioski cząstkowe, a także przytoczone tu badania tego zagadnienia przeprowadzone przez innych Autorów, pozwalają stwierdzić występowanie dużej stabilności na liście 100 największych korporacji amerykańskich do 1985 roku z zarysowującą się dodatkowo tendencją do umacniania się pozycji liderów tej listy, co z kolei wskazuje na zmniejszanie siły działania konkurencji, a więc głównego procesu dezintegracyjnego w gospodarce rynkowej. Formułowanie wniosków dotyczących okresu od 1995 roku wymaga podejścia sektorowego do badanych procesów.

\section{BIBLIOGRAFIA}

Adelman M. A., The Measurement of Industrial Concentration, „The Review of Economics and Statistics", t. 33, nr 4 (listopad, 1951), s. 269-296.

Collins N. R., Preston, L. E., The Size Structure of the Largest Industrial Firms, 1909-1958, „The American Economic Review”, t. 51, nr 5 (grudzień 1961), s. 986-1011.

Fortune 500, http://money.cnn.com/magazines/fortune/fortune500_archive/full/1955/ (stan na 20.09.2011).

Kaplan A. D. H., Big Enterprise In a Competitive System, Brookings Institution, Washington 1954.

Kozak S., Konsolidacja sektora bankowego w USA, Wydawnictwo CeDeWu, Warszawa 2005.

${ }^{1}$ Procesy fuzji i przejęć w sektorze finansowym opisuje szczegółowo S. Kozak, Konsolidacja sektora bankowego w USA, Wydawnictwo CeDeWu, Warszawa 2005, a także S.G. Kozłowski, Ameryka wspótczesna: pejzaż polityczny i spoteczno-gospodarczy, Wydawnictwo UMCS, Lublin 2008, s. 263-263. W tezach podejmowanych przez tych Autorów należy doszukiwać się źródeł takiego wzrostu znaczenia sektora finansowego w Stanach Zjednoczonych. 
Kozłowski S.G., Ameryka wspótczesna: pejzaż polityczny i spoteczno-gospodarczy, Wydawnictwo UMCS, Lublin 2008.

Mermelstein D., Large Industrial Corporations and Asset Shares, „The American Economic Review", t. 59, nr 4, cz. 1 (wrzesień 1969), s. 531-541.

Statistical Abstract of United States, http://www.census.gov/prod/www/abs/statab.html (stan na 20.09.2011).

Stonebraker, R. J., Turnover and Mobility among the 100 Largest Firms: An Update, „The American Economic Review”, t. 69, nr 5 (grudzień 1979), s. 968-973.

\section{PROCESY ZACHODZACE W GRUPIE NAJWIĘKSZYCH KORPORACJI AMERYKAŃSKICH W LATACH 1955-2011}

\section{STRESZCZENIE}

Artykuł przedstawia procesy integracji i dezintegracji w gospodarce przez pryzmat listy 100 największych korporacji amerykańskich w latach 1955-2011. Badania oparte są na różnych statystykach i wskaźnikach, m.in. współczynniku Giniego zróżnicowania rozkładu wartości aktywów korporacji, współczynnikach koncentracji, współczynniku korelacji pomiędzy pozycjami zajmowanymi w różnych latach oraz na statystykach wyjść i wejść na listę. Przeprowadzone badania pozwalają na sformułowanie wniosków o względnie stabilnej sytuacji na liście do roku 1995 oraz o konieczności zastosowania innego podejścia wobec okresu 1995-2011.

\section{PROCESSES OCCURRING \\ IN THE GROUP OF THE LARGEST AMERICAN CORPORATIONS IN YEARS 1955-2011}

\section{SUMMARY}

The article presents the processes of integration and disintegration in the economy due to the list of 100 largest U.S. corporations in years 1955-2011. The analyses are based on various statistics and indicators, including the Gini coefficient of distribution variation of corporate assets, concentration ratios, coefficient of correlation between the positions occupied in different years and the statistics of entrants and exits on the list. The studies allow to draw conclusions about a relatively stable situation in a list to the year of 1995 and the necessity of a different approach to the period of 1995-2011. 